\title{
RESEARCH PAPER \\ Spatial distribution of head smut (Sporisorium reilianum) of corn in Mexico
}

\author{
Jesús Ricardo Sánchez-Pale ${ }^{1}$, José Francisco Ramírez-Dávila, Andrés \\ González-Huerta ${ }^{1}$, and Carlos de León ${ }^{2}$ \\ ${ }^{1}$ Postgrado en Ciencias Agropecuarias y Recursos Naturales. Universidad Autónoma del Estado de México. \\ Toluca, Estado de México Apartado Postal 435. México. \\ ${ }^{2}$ Postgrado en Fitopatología. Colegio de Postgraduados, Texcoco, Edo. de México, C.P 56230, México.
}

\begin{abstract}
J. R. Sánchez-Pale, J. F. Ramírez-Dávila, A. González-Huerta, and C. de León. 2011. Spatial distribution of head smut (Sporisorium reilianum) of corn in Mexico. Cien. Inv. Agr. 38(2):253-263. Knowledge about the spatial distribution of agricultural diseases is important for the elaboration of integrated pest management programs. Such knowledge allows the exact and adept development of sampling methods, control methods and risk valuation. Despite its importance, there have been few studies of the spatial distribution of head smut of corn in Mexico. This study aimed to determine the spatial distribution of this disease during the year 2007 in the State of México and to establish its spatial behavior with geostatistical techniques. Five points per plot were chosen for sampling. For each sampling point, 100 plants in a single row were counted, and the plants that presented symptoms of the disease were recorded. The geostatistical analysis used this data to estimate the experimental semivariogram, which was adjusted using theoretical models (spherical, exponential, Gaussian and logarithmic), in the Variowin 2.2 program. The semivariogram was verified by the geostatistical interpolation method or kriging through the cross validation, and cluster maps were subsequently made. The disease was present in 32 locations of 31 counties in Mexico State. All the locations presented a spatial behavior aggregated to the disease. Twenty-four locations were adjusted to the spherical model, seven locations were adjusted to the exponential model, and one location was fit to the Gaussian model. Lastly, it was possible to set aggregation maps in all models.
\end{abstract}

Keys words: Geostatistic, Sphacelatheca reiliana, Sporisorium reilianum, Zea mays.

\section{Introduction}

Corn (Zea mays L.) is the main crop in Mexico State, accounting for more than $75 \%$ of the cultivated surface. A total of 579,407 ha were planted with corn during the 2006 agricultural

Received January 20, 2010. Accepted May 9, 2011. Corresponding author: jframirezd@uaemex.mx year (SAGARPA, 2006). This crop presents a very wide range of phytosanitary problems, including economically important pests like May beetles (Phyllophaga sp., Anomala sp., Cyclocephala sp., etc.), corn rootwoms ( $D i$ abrotica sp.) and false wireworms (Eleodes sp.) as well as diseases like horse's tooth (Claviceps gigantea) and rayado fino (a maize virus). Some rodents (Rattus rattus, Rattus norvegicus and Sigmodon hispidus), squirrels, Que- 
retaro pocket gophers (Cratogeomys sp. and Orthogeomys sp.), grasshoppers (Brachystola $s p$., Melanoplus sp. and Sphenarium sp.), white speck and beet armyworms (Mythimna unipuncta and Spodoptera exigua) have also been detected, and the disease known as corn head smut (Sporisorium reilianum) (Kühn) Clinton) (=Sphacelotheca reiliana) ((NOM-FITO-081, 2001) extends through different agricultural regions of Mexico State.

Reports from the Comité Estatal de Sanidad Vegetal del Estado de México (CESAVEM) indicate that the commercial maize crops from Valles Altos of Mexico State are affected by a quarantine disease known as head smut. S. reiliana attacks plant spikes and ears and reduces crop yields up to $15 \%$. It extends through several Rural Development Districts, including Toluca, Zumpango, Texcoco, Atlacomulco, Jilotepec and Valle de Bravo, among others. These reports indicate that head smut attacks most commercial varieties and hybrids (CESAVEM, 2005). Recently, attacks of head smut have been observed on native maize cultivars, which risks maize genetic diversity considering that the maize ancestor teosinte (Z. mays ssp. mexicana) is affected by this fungus.

Head smut may be fought by cultural, chemical, and genetic methods. However, few fungicides are both recommended and available commercially, and all of them used are for seed treatment (CICOPLAFEST, 1998; Dirección General de Sanidad Vegetal, 1998; Thomson-PLM, 2007). Genetic control is more efficient and economical, but the degree of resistance to the disease of commercial and native materials is unknown; therefore, evaluation is required.

Correct control is strongly related to knowledge of the spatial distribution of the disease. Even now, this knowledge is lacking at both the plot and regional levels with regard to scientific support for the selection of efficient and sustainable alternative integrated controls. Several researchers have indicated that knowledge on the spatial distribution of the disease is widely important for the development of integrated management programs. This knowledge allows for the accurate and efficient development of sampling methods, control methods and risk valuation (Taylor, 1961; Boiteu et al., 1979; Ruesink, 1980; Taylor, 1984; Fleischer et al., 1999; González-Andujar et al., 2006). The advantage of geostatistics is the characterization of the spatial distribution along multiple scales and directions, in addition to the independence from the mean and sample variance relationship. Geostatistical methods provide a measurement from the spatial dependence respect to others methods because they consider the bidimensional nature of the distribution of organisms and also allow the elaboration of useful maps (Isaaks and Srivastava, 1988; Oliver and Webster, 1991; Rossi et al., 1992; Speight et al., 1998; Sciarretta et al., 2001; Blom and Fleischer, 2001). The main objective of precision agriculture is the optimized global management of agricultural fields using of geotechnologies (e.g., global positioning systems, geographic information systems, geostatistics, and remote perception). Therefore, one of the objectives of precision agriculture is the management of control methods in specific zones of disease infestation as affected areas are visualized precisely on maps generated by kriging, which allows a more appropriate management strategy to be determined. Thus, economic and environmental costs are reduced. It is possible to establish spatial distribution maps of the disease and the percentage of infestation in areas under study by geostatistics. Therefore, economic and environmental savings are achievable because maize seeds can be sown with fungicides in specific zones of disease infestation. Geostatistic spatial modeling has been used to model leaf scorch disease in almond tree leaves caused by Xylella fastidiosa (Groves et al., 2005), lettuce drop caused by Sclerotinia minor and Sclerotinia sclerotiorum (Hao and Subbarao, 2005) in California, damage caused by Pratylenchus crenatus in carrots (Hay and Pethybridge, 2005) in Tasmania, strawberry leaf spot caused by $\mathrm{Myco}$ sphaerella fragariae (Turechek and Madden, 1999) in Ohio, and the association of Beet necrotic yellow vein and Beet soilborne mosaic viruses in beet fields (Workneh et al., 2003). Spatial modeling is not yet available for Sporisorium reilianum. 
Information on the spatial distribution of corn head smut is important. The integration of a cluster of computer programs and applications allows for the management of organized data that is spatially referenced for visualization on maps and considers all the agroclimatic information available. This analysis will help improve the health of maize and other crops of agricultural importance. These elements enable the use of technology in precision agriculture that benefits Mexican farmers. In this context, the following objectives have been determined: a) determination of the spatial distribution of head smut in Mexico State and b) determination of the maize surface infested with head smut.

\section{Materials and methods}

Sampling was conducted in 32 localities in the 31 municipalities with disease records (CESAVEM, 2005) when the commercial varieties and hybrids of maize were at milky stage of grain filling (R3) (Ritchie and Hanway, 1982). The geographic points for 100 plots were located with a differential global positioning system (DGPS, Model SPS351, Trimble, United States of America). Disease incidence was determined by dividing each plot into five quadrants or sample points and counting 100 consecutive plants in the same row. Plants presenting symptoms of the disease were recorded. For each sampling plot, the municipality, locality, and incidence of disease were recorded.

Data from samplings obtained during the 2007 agricultural cycle in 31 municipalities from Mexico State were analyzed (CESAVEM, 2005).

The geostatistical analysis consisted of 1) estimation of the omnidirectional semivariogram, 2) estimation of the parameters of the semivariogram model, and 3) estimation of the infested surface (maps) using points (estimations) obtained by kriging. The semivariogram was estimated using data collected from the disease sampling sites, and the experimental value of the semivariogram was calculated by the following expression (Journel and Huijbregts, 1978; Isaaks and Srivastava, 1989): $\gamma^{*}(h)=\frac{1}{2 N(h)} \sum_{i=1}^{N(H)}\left[z\left(x_{i}+h\right)-z\left(x_{i}\right)\right]^{2}$

where $\gamma^{*}(h)$ is the experimental value of the semivariogram for the distance interval $h, N(h)$ is the number of pairs of sample points separated by the distance interval $h, z\left(x_{i}\right)$ is the value of the variable of interest in the sample point $x_{i}$, and $z\left(x_{i}+h\right)$ is the variable of interest in the sample point $x_{i}+h$. Any mathematical function may be used for modeling a semivariogram, provided that positive and defined conditions are fulfilled (Armstrong and Jabin, 1981). In practice, one of the functions known for fulfilling these conditions was chosen as a model (Isaaks and Srivastava, 1989). The visual selection of a function that seems to be adjusted to the experimental values of the semivariogram and further validation of that selection are common procedures (Englund and Sparks, 1988).

The different models adjusted to the experimental semivariograms were validated by a procedure called cross-validation (Isaaks and Srivastava, 1989). In this procedure, a sample value is eliminated, and the geostatistical interpolation method called kriging is used along the semivariogram model for validation to estimate the variable of interest at that sample point from the remaining sample values. This procedure is carried out successively for all the sample points, and the differences between the experimental values and the values estimated are summarized by cross-validation statistical methods (Isaaks and Srivastava, 1989; Hevesi et al., 1992). The model parameters for validation are the nugget effect, the sill and the range, which are modified in a trial-and-error procedure until adequate cross-validation statistics are obtained. These statistical values are as follows:

a) Mean estimation error (MEE)

$$
\text { SMSE }=\frac{1}{n} \sum_{i=1}^{n} \frac{\left[z^{*}\left(x_{i}\right)-z\left(x_{i}\right)\right]}{\sigma k}
$$

where $z^{*}\left(x_{i}\right)$ is the estimation of the variable of interest in the point $x_{i}, z\left(x_{i}\right)$ is the value measured from the variable of interest in the point 
$x_{i}$, and $\mathrm{n}$ is the number of sample points used in the interpolation. The MEE must be significantly equal to 0 (by a t-test), which might indicate that the semivariogram model allows for the calculation of unbiased estimates.

b) Mean squared error (MSE)

$$
\operatorname{MSE}=\frac{1}{n} \sum_{i=1}^{n} \underline{\left[z^{*}\left(x_{i}\right)-z\left(x_{i}\right)\right]^{2}}
$$

As a practical rule, a semivariogram model is considered adequate if the statistical parameter is close to zero (Hevesi et al., 1992).

c) Standardized Mean Squared Error (SMSE)

$$
\operatorname{SMSE}=\frac{1}{n} \sum_{i=1}^{n} \frac{\left[z^{*}\left(x_{i}\right)-z\left(x_{i}\right)\right]}{\sigma k}
$$

where $\sigma_{k}$ is the standard deviation of the error expected in the estimation with kriging. The validity of the model is satisfied if the SMSE is between the values $1 \pm 2(2 / N)^{0.5}$.

d) Another statistical method for validating the model fit consists of an error variance lower than the sample variance.

The level of spatial dependence of the data obtained in the samplings was calculated to determine their degree of dependence with regard to their relationship strength. This value is obtained by dividing the nugget effect by the sill and expressing the result as a percentage. If the result is lower than $25 \%$, the level of spatial dependence is high; if it is between 26 and $75 \%$, the level of spatial dependence is moderate; and if it is higher than $76 \%$, the level of spatial dependence is low (Cambardella et al., 1994; López-Granados et al., 2002).

Kriging was used once the corresponding semivariogram models were validated. Kriging is a geostatistical interpolation method that avoids biased values associated with unsampled points for the elaboration of population density maps of a disease. The incidence estimations of corn head smut in the different localities studied were made using the program VarioWin 2.2
(1998). Once the corresponding estimations were obtained with ordinary Kriging for each locality, maps were constructed indicating the spatial distribution of corn head smut infestations in the different localities of Mexico State. The estimations obtained for the disease were represented on a map by the program Surfer 9 (Golden Surfer, Colorado, USA).

The real surface infested by corn head smut was estimated from the maps that were elaborated using the Surfer 9.0 program.

\section{Results}

The disease appeared in 32 localities in $31 \mathrm{mu}-$ nicipalities of Mexico State; the incidence of the disease varied between 0.2 and $5.2 \%$ within the different localities evaluated. The highest field incidence of head smut (5.2\%) occurred in the locality of San José Ixtapa, municipality of Temascalcingo. The total surface with disease incidence was 927.01 ha (Table 1), corresponding to $9.96 \%$ of the total surface sampled in Mexico State in 2007.

The cross-validation statistical analysis (Table 2) indicated that the semivariograms obtained were adjusted to the spherical model for 23 localities; for 7 localities, the semivariograms were adjusted to the exponential model, and for one locality, the semivariogram was adjusted to the Gaussian model. These data showed an aggregated spatial structure of corn head smut in all the localities without nugget effect. The values of the nugget effect were equal to zero in all the model semivariograms obtained, indicating that $100 \%$ of the variation in the disease distribution could be explained by the spatial structure determined in the respective semivariograms.

With regard to the sill, the values ranged from 0.00020 to 7.34667 for the spherical model and 0.00367 to 0.31853 for the exponential model, and a sill value of 0.00063 was found for the Gaussian model. The range values varied between 72.0 and $2735.7 \mathrm{~m}$ for the spherical model and 112.4 to $988.92 \mathrm{~m}$ for the exponential model, and a range value of 1340.5 was found for the Gaussian mod- 
Table 1. Corn head smut (Sporisorium reilianum) incidence, affected surfaces, and estimates of the infested and uninfested surfaces by county and locality in 2007.

\begin{tabular}{|c|c|c|c|c|c|c|}
\hline No. & County & Location & Area (ha) & Incidence $(\%)$ & $\%$ Infested & $\%$ Uninfested \\
\hline 1 & Acambay & San Antonio Detiña & 8.30 & 0.2 & 12 & 88 \\
\hline 2 & Almoloya de Juarez & Santa Juana & 10.00 & 0.2 & 54 & 46 \\
\hline 3 & Amanalco & San Juan & 5.06 & 0.2 & 23 & 77 \\
\hline 4 & Amatepec & Ayuquila & 2.80 & 1.2 & 44 & 56 \\
\hline 5 & Apaxco & Santa María Apaxco & 3.90 & 0.6 & 38 & 62 \\
\hline 6 & Atlacomulco & Tic Tic & 15.00 & 1.0 & 15 & 85 \\
\hline 7 & Calimaya & Calimaya & 67.30 & $0.4-0.6$ & 27 & 73 \\
\hline 8 & Chalco & San Martin Cuautlalpan & 32.80 & $0.2-0.8$ & 29 & 71 \\
\hline 9 & Chapa de Mota & La Esperanza & 9.70 & $0.8-1.4$ & 33 & 67 \\
\hline 10 & Cocotitlan & San Andres & 42.00 & 0.2 & 63 & 37 \\
\hline 11 & Donato Guerra & San Jose Tiloxtoc & 3.29 & $0.2-0.4$ & 34 & 66 \\
\hline 12 & Ixtapan del Oro & El Salto y Mesas & 4.19 & $0.2-0.8$ & 39 & 61 \\
\hline 13 & Jilotepec & San Pablo Huantepec & 30.10 & $0.2-1.8$ & 30 & 70 \\
\hline 14 & Juchitepec & Juchitepec & 9.00 & 0.2 & 83 & 17 \\
\hline 15 & Metepec & Metepec & 161.30 & $0.2-1.2$ & 86 & 14 \\
\hline 16 & Otzoloapan & El Calvario & 3.49 & $0.2-0.8$ & 28 & 72 \\
\hline 17 & Rayon & Rayon & 79.10 & $0.2-0.8$ & 45 & 55 \\
\hline 18 & San Felipe Progreso & S. F. progreso & 16.80 & 1.2 & 32 & 68 \\
\hline 19 & San Mateo Atenco & Guadalupe & 95.00 & $0.4-0.8$ & 37 & 63 \\
\hline 20 & Soyaniquilpan & San Jose Deguedo & 5.60 & $0.4-1.6$ & 62 & 38 \\
\hline 21 & Temascalcingo & San Jose Ixtapa & 68.40 & $0.2-5.2$ & 26 & 74 \\
\hline 22 & Temascaltepec & La Finca & 18.79 & $0.4-2.6$ & 84 & 16 \\
\hline 23 & Temoaya & Taborda & 9.00 & 0.8 & 14 & 86 \\
\hline 24 & Tenancingo & San Jose El Cuartel & 9.01 & 1.2 & 12 & 88 \\
\hline 25 & Tenango del Aire & Tenango del Aire & 53.00 & $0.2-0.4$ & 87 & 13 \\
\hline 26 & Tenango del Valle & Tenango & 21.10 & $0.2-0.6$ & 85 & 15 \\
\hline 27 & Tianguistenco & Tianguistenco & 12.40 & 0.4 & 18 & 82 \\
\hline 28 & Tlalmanalco & Tlalmanalco & 64.80 & $0.2-0.8$ & 77 & 23 \\
\hline \multirow[t]{2}{*}{29} & \multirow[t]{2}{*}{ Valle de Bravo } & Santa Teresa T. & \multirow{2}{*}{18.24} & $0.2-1.0$ & 46 & 54 \\
\hline & & Santa Magdalena T. & & $0.2-1.0$ & 19 & 81 \\
\hline 30 & Villa Victoria & Laguna Seca & 5.54 & 0.2 & 13 & 87 \\
\hline \multirow[t]{2}{*}{31} & Xonacatlan & Ejido Xonacatlan & 60.00 & $0.2-2.0$ & 82 & 18 \\
\hline & & Total & 927.01 & & & \\
\hline
\end{tabular}

el (Table 2). These values indicate that the spatial dependence between points was highly variable in the different localities and that the aggregation zones had different sizes. The values within the appropriate range of the cross-validation statistical values (Table 3 ) allow for the validation of the adjusted models. The level of spatial dependence was high for all cases.

Zones of disease aggregation were observed in all localities (Figure 1), which for allows their visualization. The variable surface dimensions indicated on the maps occur due to the differences existing in the location of the corn head smut plots within each locality. The distribution of corn head smut populations was observed in specific zones of the localities with incidences above $1.4 \%$, which suggests a relationship between aggregated distribution and disease incidence. Irregular aggregations and only one continuous aggregation were also obtained, expressed by the Gaussian model, for the locality of Juchitepec; it is noteworthy that these patterns of aggregations were inferred from the adjusted semivariogram (Goovaerts, 1997). No association was observed between the incidence of the disease and higher number of aggregation centers, nor were lower localities with lower disease incidences found to have the highest free areas. The highest aggregate presence of the disease was observed along the borders of the map, although the highest incidences tended to be located toward the center of the map for most localities. 
Table 2. Parameters (nugget, sill and range) in the adjusted models of corn head smut (Sporisorium reilianum) semivariograms by county and locality in 2007.

\begin{tabular}{|c|c|c|c|c|c|c|c|}
\hline No. & County & Model & Nugget & Sill & Range & $\begin{array}{c}\text { Nugget/Sill } \\
(\%)\end{array}$ & $\begin{array}{c}\text { Level of space } \\
\text { dependence }\end{array}$ \\
\hline 1 & Acambay & Spherical & 0 & 7.34667 & 142.3 & 0.00 & High \\
\hline 2 & Almoloya de Juarez & Spherical & 0 & 0.00017 & 1022.1 & 0.00 & High \\
\hline 3 & Amanalco & Spherical & 0 & 0.00029 & 97.6 & 0.00 & High \\
\hline 4 & Amatepec & Exponential & 0 & 0.31853 & 112.4 & 0.00 & High \\
\hline 5 & Apaxco & Spherical & 0 & 0.00070 & 991.3 & 0.00 & High \\
\hline 6 & Atlacomulco & Exponential & 0 & 0.00534 & 436.4 & 0.00 & High \\
\hline 7 & Calimaya & Spherical & 0 & 0.00368 & 1157.1 & 0.00 & High \\
\hline 8 & Chalco & Spherical & 0 & 0.00420 & 72.0 & 0.00 & High \\
\hline 9 & Chapa de Mota & Spherical & 0 & 0.00898 & 1084.3 & 0.00 & High \\
\hline 10 & Cocotitlan & Exponential & 0 & 0.00367 & 988.92 & 0.00 & High \\
\hline 11 & Donato Guerra & Spherical & 0 & 0.00121 & 206.5 & 0.00 & High \\
\hline 12 & Ixtapan del Oro & Spherical & 0 & 0.00469 & 276.4 & 0.00 & High \\
\hline 13 & Jilotepec & Spherical & 0 & 0.01627 & 1996.4 & 0.00 & High \\
\hline 14 & Juchitepec & Gaussian & 0 & 0.00063 & 1340.5 & 0.00 & High \\
\hline 15 & Metepec & Exponential & 0 & 0.03983 & 710.8 & 0.00 & High \\
\hline 16 & Otzoloapan & Spherical & 0 & 0.00349 & 321.5 & 0.00 & High \\
\hline 17 & Rayon & Spherical & 0 & 0.00851 & 276.92 & 0.00 & High \\
\hline 18 & San Felipe Progreso & Spherical & 0 & 0.00289 & 949.43 & 0.00 & High \\
\hline 19 & San Mateo Atenco & Spherical & 0 & 0.01037 & 1159.0 & 0.00 & High \\
\hline 20 & Soyaniquilpan & Spherical & 0 & 0.02202 & 2735.7 & 0.00 & High \\
\hline 21 & Temascalcingo & Exponential & 0 & 0.34448 & 1034.9 & 0.00 & High \\
\hline 22 & Temascaltepec & Spherical & 0 & 0.29853 & 74.0 & 0.00 & High \\
\hline 23 & Temoaya & Spherical & 0 & 0.00221 & 681.9 & 0.00 & High \\
\hline 24 & Tenancingo & Spherical & 0 & 0.00712 & 852.2 & 0.00 & High \\
\hline 25 & Tenango del Aire & Spherical & 0 & 0.00155 & 180.4 & 0.00 & High \\
\hline 26 & Tenango del Valle & Spherical & 0 & 0.00619 & 950.5 & 0.00 & High \\
\hline 27 & Tianguistenco & Exponential & 0 & 0.03955 & 670.8 & 0.00 & High \\
\hline 28 & Tlalmanalco & Exponential & 0 & 0.00676 & 359.4 & 0.00 & High \\
\hline \multirow[t]{2}{*}{29} & Valle de Bravo & Exponential & 0 & 0.01869 & 186.2 & 0.0 & High \\
\hline & & Spherical & 0 & 0.02893 & 134.5 & 0.0 & High \\
\hline 30 & Villa Victoria & Spherical & 0 & 0.00020 & 453.8 & 0.0 & High \\
\hline 31 & Xonacatlan & Spherical & 0 & 0.00624 & 232.6 & 0.0 & High \\
\hline
\end{tabular}

The uninfested area was estimated to range from $13.0 \%$ (Tenango del Aire) to $88.0 \%$ (Acambay) of the total area sampled (Table 1), with a mean value of $57.32 \%$. The largest surfaces infected were estimated for Tenango del Aire (87\%), Metepec $(86 \%)$ and Tenango del Valle (85\%); the average value was $42.67 \%$. The maps allowed for identifying infected areas and free infestation areas.

\section{Discussion}

In this study, the level of spatial dependence showed the aggregated distribution of corn head smut disease in Mexico State in all localities evaluated. The differences in the disease incidences and the number of properties infested 
Table 3. Values of the cross-validation statistics in the aggregation model of corn head smut (Sporisorium reilianum) by county in 2007: mean estimation error (MEE), mean squared error (MSE) and standardized mean squared error (SMSE).

\begin{tabular}{|c|c|c|c|c|c|c|c|c|}
\hline No. & County & Sample Size & $\begin{array}{l}\text { Sample } \\
\text { Average }\end{array}$ & $\begin{array}{l}\text { Variance } \\
\text { Sample }\end{array}$ & MEE & $\begin{array}{l}\text { Variance of } \\
\text { the errors }\end{array}$ & MSE & SMSE \\
\hline 1 & Acambay & 100 & 0.002 & 0.00040 & $0.11^{\mathrm{ns}}$ & 0.0001 & 0.07 & 1.09 \\
\hline 2 & Almoloya de Juarez & 100 & 0.002 & 0.00040 & $0.08^{\mathrm{ns}}$ & 0.0003 & 0.09 & 1.07 \\
\hline 3 & Amanalco & 100 & 0.002 & 0.00040 & $0.10^{\mathrm{ns}}$ & 0.0001 & 0.01 & 1.10 \\
\hline 4 & Amatepec & 100 & 0.012 & 0.01454 & $0.09^{\mathrm{ns}}$ & 0.0105 & 0.11 & 1.11 \\
\hline 5 & Apaxco & 100 & 0.006 & 0.00356 & $0.13^{\mathrm{ns}}$ & 0.0021 & 0.10 & 1.08 \\
\hline 6 & Atlacomulco & 100 & 0.010 & 0.00990 & $0.12^{\mathrm{ns}}$ & 0.0075 & 0.12 & 1.12 \\
\hline 7 & Calimaya & 100 & 0.016 & 0.00854 & $0.09^{\text {ns }}$ & 0.0032 & 0.04 & 1.02 \\
\hline 8 & Chalco & 100 & 0.029 & 0.01006 & $0.11^{\mathrm{ns}}$ & 0.0083 & 0.12 & 1.11 \\
\hline 9 & Chapa de Mota & 100 & 0.022 & 0.02552 & $0.02^{\mathrm{ns}}$ & 0.0168 & 0.13 & 1.09 \\
\hline 10 & Cocotitlan & 100 & 0.016 & 0.00454 & $0.13^{\text {ns }}$ & 0.0027 & 0.08 & 1.14 \\
\hline 11 & Donato Guerra & 100 & 0.006 & 0.00196 & $0.14^{\mathrm{ns}}$ & 0.0008 & 0.10 & 1.12 \\
\hline 12 & Ixtapan del Oro & 100 & 0.022 & 0.01352 & $0.08^{\mathrm{ns}}$ & 0.0113 & 0.02 & 1.10 \\
\hline 13 & Jilotepec & 100 & 0.030 & 0.03710 & $0.10^{\mathrm{ns}}$ & 0.0254 & 0.07 & 1.05 \\
\hline 14 & Juchitepec & 100 & 0.004 & 0.00078 & $0.12^{\mathrm{ns}}$ & 0.0003 & 0.13 & 1.02 \\
\hline 15 & Metepec & 100 & 0.079 & 0.05666 & $0.10^{\mathrm{ns}}$ & 0.0408 & 0.04 & 1.11 \\
\hline 16 & Otzoloapan & 100 & 0.016 & 0.00774 & $0.14^{\mathrm{ns}}$ & 0.0059 & 0.12 & 1.15 \\
\hline 17 & Rayon & 100 & 0.023 & 0.01277 & $0.10^{\mathrm{ns}}$ & 0.0103 & 0.15 & 1.04 \\
\hline 18 & San Felipe Progreso & 100 & 0.021 & 0.02482 & $0.11^{\mathrm{ns}}$ & 0.0174 & 0.06 & 1.09 \\
\hline 19 & San Mateo Atenco & 100 & 0.020 & 0.01080 & $0.08^{\mathrm{ns}}$ & 0.0009 & 0.10 & 1.10 \\
\hline 20 & Soyaniquilpan & 100 & 0.020 & 0.02680 & $0.10^{\mathrm{ns}}$ & 0.0209 & 0.13 & 1.03 \\
\hline 21 & Temascalcingo & 100 & 0.100 & 0.42440 & $0.11^{\mathrm{ns}}$ & 0.3302 & 0.11 & 1.13 \\
\hline 22 & Temascaltepec & 100 & 0.626 & 0.34052 & $0.12^{\mathrm{ns}}$ & 0.3302 & 0.14 & 1.09 \\
\hline 23 & Temoaya & 100 & 0.008 & 0.00634 & $0.11^{\mathrm{ns}}$ & 0.0047 & 0.09 & 1.11 \\
\hline 24 & Tenancingo & 100 & 0.012 & 0.01426 & $0.10^{\mathrm{ns}}$ & 0.0105 & 0.11 & 1.02 \\
\hline 25 & Tenango del Aire & 100 & 0.014 & 0.00500 & $0.09^{\mathrm{ns}}$ & 0.0033 & 0.05 & 1.15 \\
\hline 26 & Tenango del Valle & 100 & 0.016 & 0.00694 & $0.10^{\mathrm{ns}}$ & 0.0049 & 0.16 & 1.07 \\
\hline 27 & Tianguistenco & 100 & 0.004 & 0.00160 & $0.08^{\mathrm{ns}}$ & 0.0011 & 0.04 & 1.05 \\
\hline 28 & Tlalmanalco & 100 & 0.023 & 0.00917 & $0.11^{\mathrm{ns}}$ & 0.0075 & 0.14 & 1.10 \\
\hline \multirow[t]{2}{*}{29} & Valle de Bravo & 100 & 0.056 & 0.02726 & $0.07^{\mathrm{ns}}$ & 0.0204 & 0.013 & 1.12 \\
\hline & & 100 & 0.074 & 0.03892 & $0.11^{\mathrm{ns}}$ & 0.0277 & 0.11 & 1.13 \\
\hline 30 & Villa Victoria & 100 & 0.002 & 0.00040 & $0.13^{\mathrm{ns}}$ & 0.0002 & 0.08 & 1.04 \\
\hline 31 & Xonacatlan & 100 & 0.041 & 0.05122 & $0.10^{\mathrm{ns}}$ & 0.0481 & 0.14 & 1.12 \\
\hline
\end{tabular}

$1 \pm 2(2 / \mathrm{N}) 0.5=1 \pm 0.45$, ns: do not differ significantly $(\mathrm{P}=0.05)$.

led to the different amount of aggregation centers of the disease. The validation of the semivariograms from each locality supported the aggregated disease distribution, which proved that the sample method and the sample scale used in the study were appropriate. The zero value in the nugget indicated that the sample error was minimal and that the sample scale was appropriate (Rossi et al., 1992). The geostatistical analysis proved to be an appropriate tool for the study of the spatial distribution of the disease.

Only the localities with disease incidences higher than $1.4 \%$ were associated with a spa- tial distribution of the disease adjusted to the spherical model, which indicates that there are zones in those localities where head smut is more evident (Table 1 and 3 ) than in the rest of the sampled points. This pattern proves the existence of environmental conditions or susceptible maize genotypes favoring the expression of the disease under this spatial distribution. This association between the disease incidence and the aggregated distribution can provide early knowledge of the spatial behavior of the disease, which could guide monitoring and direct control measures to specific points with high disease incidences. 

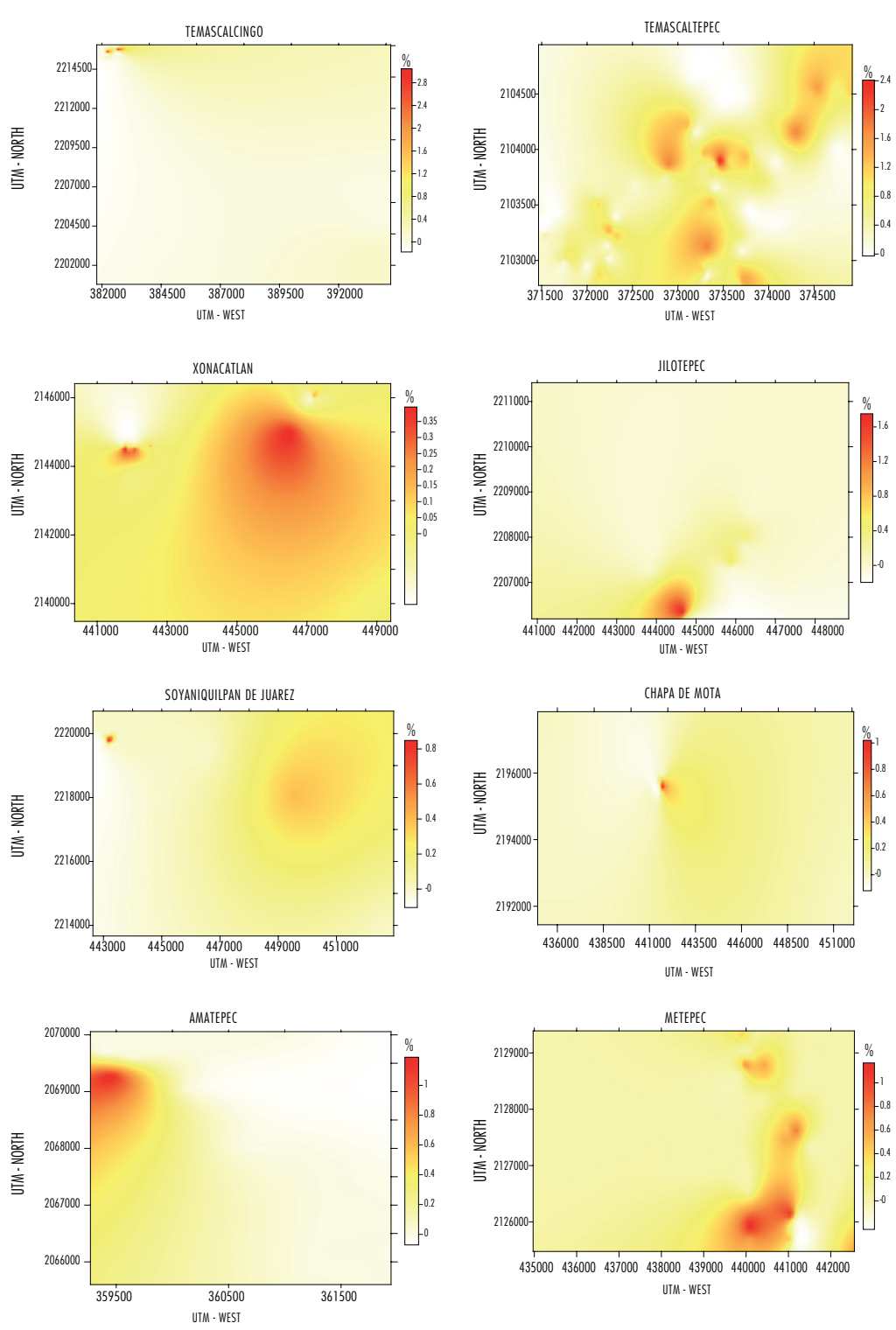

Figure 1. Density maps of head smut of corn in different locations in $2007(\%=$ Incidence). Only the localities with higher incidences of corn head smut are indicated.

The spatial distribution of the disease in localities with disease incidences between 0.2 and $1.2 \%$ were described with exponential and spherical models. Localities for which the semivariogram was adjusted to an exponential model were not associated with disease incidences above $1.4 \%$.

The localities for which the semivariogram was adjusted to the exponential model showed irregular or random distribution of corn head smut within the areas under study, which suggests the existence of a single definable factor.
CESAVEM reports (2005) have indicated that both commercial varieties and hybrids are more susceptible to the disease than native maize genotypes; therefore, the distribution of commercial varieties and hybrids might be irregular within the locality, or there might be a higher abundance of native maize genotypes.

The adjustment of the Gaussian model in the locality of Juchitepec, which had a corn head smut incidence of $0.2 \%$, indicates that the disease was expressed continuously with respect to the 
sampled points (Table 3). There is a continuous aggregation with respect to the collected data (Goovaerts, 1997), which suggests that different environmental factors favor disease aggregation in a continuous form or expansion of the disease.

The geostatistical spatial models of corn head smut obtained in this work are consistent with the geostatistical models of leaf scorch disease in almond tree leaves caused by Xylella fastidiosa, obtained by Groves et al. (2005), and the models of lettuce drop in California caused by Sclerotinia minor and Sclerotinia sclerotiorum, obtained by Hao and Subbarao (2005).

Likewise, damage caused by Pratylenchus crenatus in carrots (Hay and Pethybridge, 2005) in Tasmania, strawberry leaf spot caused by $M y$ cosphaerella fragariae (Turechek and Madden, 1999) in Ohio, and the association of Beet necrotic yellow vein and Beet soilborne mosaic viruses in beet fields (Workneh et al., 2003) have been modeled. Similarly, Larkin et al. (1995) modeled the epidemic of Phytophthora capsici in Chilean fields, which allowed determination of the spatial patterns of the disease and the water content in the soil as well as their relationship with the development of the disease at the plot level.

The maps obtained show that the disease does not cover $100 \%$ of the area in the locality; that is, the distribution is irregular. These results are consistent with reports by Roumagnac et al. (2004) of irregular distribution of Xanthomonas axonopodis pv. allii in onions and Gavassoni et al. (2001) of irregular distribution of Heterodera glycines in soybeans. Similarly, the distribution of Colletotrichum kahawae in coffee was reported as irregular (Mouen Bedimo et al., 2007). The highest percentage of uninfested area was associated with the spherical model for the localities with disease incidences lower than $1.8 \%$, except for the locality of Temascalcingo, while the highest percentages of infected surface estimated were associated with the three models. No relationship was found between the highest disease incidence percentages determined in each locality and the highest percentages of infested areas estimated.

The results suggest applications focused on the control methods within each locality, in the areas actually infested with the disease, that would enable economic and environmental savings. Both the localized use of maize seed treated with fungicide and the elimination of diseased plants justify the use of precision agriculture techniques for the control of corn head smut infestations.

The spatial distribution of the disease could be explained by the geostatistical semivariograms revealing the aggregation behavior of corn head smut, which are supported by the maps made by kriging in real time. Corn head smut did not present infestation distributions in $100 \%$ of the surface in the localities analyzed. The aggregation maps obtained can be used to determine control strategies that focus on areas infested with head smut.

The results of this work represent the first report on the spatial distribution of corn head smut disease obtained with the use of geostatistical techniques.

\section{Resumen}

J. R. Sánchez-Pale, J. F. Ramírez-Dávila, A. González-Huerta y C. de León. 2011. Distribución espacial del carbón de la espiga (Sporisorium reilianum) del maíz en México. Cien. Inv. Agr. 38(2): 253-263. El conocimiento de la distribución espacial de las enfermedades en el ámbito agrícola es de gran importancia para la elaboración de programas de manejo integrado. Tal conocimiento permite el desarrollo exacto y eficiente de métodos de muestreo, de tácticas de control y de valoración de riesgos. A pesar de dicha importancia, se carece de estudios sobre el comportamiento espacial del carbón de la espiga del maíz en México. El presente estudio se realizó con la finalidad de determinar la distribución espacial de la enfermedad durante el año 2007 en el Estado de México así como la de establecer su 
comportamiento espacial con técnicas goeoestadísticas. El muestreo consistió en establecer cinco puntos por parcela, en cada punto se contabilizaron 100 plantas en una misma hilera, registrando las que presentaban síntomas de la enfermedad. Se realizó el análisis geoestadístico para estimar el semivariograma experimental, una vez obtenido, se ajustó a un modelo teórico (esférico, exponencial, gaussiano o logarítmico) a través de los programas Variowin 2.2., su ajuste se validó a través de la validación cruzada con el método de interpolación geoestadística o krigeado. Posteriormente se elaboraron mapas de agregación de la enfermedad. Los resultados indicaron que la enfermedad se presentó en 32 localidades de 31 municipios del Estado de México; la incidencia de la enfermedad presentó un comportamiento espacial agregado en todas las localidades, en 24 la incidencia de la enfermedad se ajustaron al modelo esférico, siete al modelo exponencial y solo una se ajustó al modelo Gaussiano. En todas las localidades se lograron establecer mapas de agregación.

Palabras clave: Geoestadística, Sphacelatheca reiliana, Sporisorium reilianum, Zea mays.

\section{References}

Armstrong, M., and R. Jabin. 1981. Variogram models must be positive-definite. Mathematical Geology 13:455-459.

Blom, E., and S. Fleischer. 2001. Dynamics in the spatial structure of Leptinotarsa decemlineata (Coleoptera: Chrysomelidae). Enviromental Entomology 30:350-364.

Boiteu, G., J. Bradley, J. Van Duyn, and R. Stinner. 1979. Bean Leaf Beetle: micro-spatial patterns and sequential sampling of field populations. Environ. Entomol. 8:1139-1104.

Cambardella, C., T. Moorman, J. Novak, T. Parkin, D. Karlen, R. Turco, and A. Konopka. 1994. Field scale variability of soil properties in central Iowa soils. Soil Sci. Soc. Am. J. 58:1501-1511.

CESAVEM. 2005. Carbón de la espiga del maíz. Campaña Manejo Fitosanitario del Cultivo del Maíz. SENASICA-SAGARPA-SEDAGRO. Comité de Sanidad Vegetal del Estado de México (CESAVEM). Folleto para Productores. Toluca, Estado de México. 6 pp.

CICOPLAFEST. 1998. Catálogo oficial de plaguicidas. SEMARNAP-SECOFI-SAGAR-SSA. Comisión Intersecretarial para el Control del Proceso y Uso de Plaguicidas, Fertilizantes y Sustancias Tóxicas (CICOPLAFEST). México, D. F. 519 pp.

Dirección General de Sanidad Vegetal. 1998. Guía de plaguicidas autorizados de uso agrícola. SAGARPA. México, D. F. p. 263-265.

Englund, E., and A. Sparks. 1988. GEO-EAS (Geostatistical Environmental Assessment Software)
User's Guide. U.S. Environmental Protection Agency Document EPA/600/4-88/033. Environmental Monitoring Systems Laboratory, Las Vegas, NV, USA. 128 pp.

Fleischer, J., E. Boom, and R. Weisz. 1999. Sampling in Precision IPM: When The Objective Is a Map. Phytopathology 89: 115- 118.

Gavassoni, W.L., G.L. Tylka, and G.P. Munkvold. 2001. Relationships between tillage and spatial patterns of Heterodera glycines. Phytopathology 91:534-545.

González-Andújar J.L., C. Fernández-Quintanilla, and L. Navarrete. 2006. Population cycles in an annual plant produced by delay-density dependence. American Naturalist 168: 318-322.

Goovaerts, P. 1997. Geostatistics for natural resources evaluation. Oxford university press, Nueva York. 483 pp.

Groves, R.L., J. Chen, E.L. Civerolo, M.W. Freeman, and M.A. Viveros. 2005. Spatial analysis of almond leaf scorch disease in the San Joaquin Valley of California: Factors affecting pathogen distribution and spread. Plant Dis. 89:581-589.

Hao, J.J., and K.V. Subbarao. 2005. Comparative analyses of lettuce drop epidemics caused by Sclerotinia minor and S. sclerotiorum. Plant Dis. 89:717-725.

Hay, F.S., and S.J. Pethybridge. 2005. Nematodes associated with carrot production in Tasmania, Australia, and the effect of Pratylenchus crenatus on yield and quality of Kuroda-type carrot. Plant Dis. 89:1175-1180.

Hevesi, J., J. Istok, and A. Flint. 1992. Precipitation estimation in mountainous terrain using multi- 
variate geostatistics. Part I. Structural analysis. Journal of Applied Meteorology 31: 661-676.

Isaaks, E.H., and R.M. Srivastava. 1988. Spatial continuity measures for probabilistic and deterministic geostatistics. Mathematical Geology 20: 313-341.

Isaaks, E.H., and R.M. Srivastava. 1989. An Introduction to applied Geostatistics. Oxford University Press, New York. 561 pp.

Journel, A.G., and C.J. Huijbregts. 1978. Mining Geostatistics. Academic Press, London, U.K. $600 \mathrm{pp}$.

Larkin, R.P., M.L. Gumpertz, and J.B. Ristaino. 1995. Geostatistical Analysis of Phytophthora epidemic development in comercial bell pepper fields. Phytopathology 85:191-203.

López-Granados, F., M. Jurado-Expósito, S. Atenciano, A. García-Ferrer, M. Sánchez, and L. GarcíaTorres. 2002. Spatial variability of agricultural soil parameters in southern Spain. Plant and Soil 246:97-105.

Mouen Bedimo, J.A., D. Bieysse, C. Cilas, and J.L. Nottéghem. 2007. Spatio-temporal dynamics of arabica coffee berry disease caused by Colletotrichum kahawae on a plot scale. Plant Dis. 91:1229-1236.

NOM-081-FITO. 2001. Manejo y eliminación de focos de infestación de plagas, mediante el establecimiento o reordenamiento de fechas de siembra, cosecha y destrucción de residuos. Norma Oficial Mexicana. In: Diario Oficial de la Federación. 18 de Septiembre de 2002. México, D. F. 6 pp.

Oliver, M., and R. Webster. 1991. How geostatistics can help you. Soil use and Management 7: 206-217.

Ritchie, S.W., and J.J. Hanway . 1982. How a corn plant develops. Iowa State University of Science and Technology. Cooperative Extension Service Ames, Iowa, USA. 17 pp.

Rossi, R.; J. Mulla, G. Journel, and H. Franz. 1992. Geostatistical tools for modeling and interpret- ing ecological spatial dependence. Ecological Monographs 62:277-314.

Roumagnac, P., O. Pruvost, F. Chiroleu, and G. Hughes. 2004. Spatial and temporal analyses of bacterial blight of onion caused by Xanthomonas axonopodis pv. allii. Phytopathology 94:138-146.

Ruesink, W. 1980. Introduction to Sampling Theory. In: Sampling methods in soybean entomology. M Kogan, and D. Herzo (ed.). Springer Verlag, New York. p. 61-78.

SAGARPA. 2006. Anuario Estadístico de la Producción Agrícola en México. Secretaria de agricultura, ganadería, desarrollo rural, pesca y alimentación (SAGARPA). México, D. F. 165 pp.

Sciarretta, A., P. Trematerra, and J. Baumgärtner. 2001. Geostatistical analisis of Cydia funebrana (Lepidoptera: Tortricidae) pheromone trap catches at two spatial scales. American Entomologist 47:174-184.

Speight, M., R. Hails, M. Gilbert, and A. Foggo. 1998. Horse chestnut scale Pulvinaria regalis (Hoimoptera: Coccidae) and urban host tree environment. Ecology 79: 1503-1513.

Taylor, L. 1961. Agregation, variance and the mean. Nature 189:732-735.

Taylor, L. 1984. Assessing and interpreting the spatial distributions of insect populations. Ann. Rev. Entomol. 29:321-357.

Thomson - PLM. 2007. Diccionario de especialidades agroquímicas. Fertilizantes, agroquímicos y productos orgánicos. PLM DEAQ. México, D. F. 1904 pp.

Turechek, W.W., and L.V. Madden. 1999. Spatial pattern analysis and sequential sampling for the incidence of leaf spot on strawberry in Ohio. Plant Dis. 83:992-1000.

Workneh, F., E. Villanueva, K. Steddom, and C.M. Rush. 2003. Spatial association and distribution of Beet necrotic yellow vein virus and Beet soilborne mosaic virus in Sugar beet fields. Plant Dis. 87:707-711. 
